\title{
Case Studies of Tree Farmers in Maasin, Leyte Island, the Philippines
}

\author{
Melissa Gordon \\ School of Natural and Rural Systems Management \\ The University of Queensland, Gatton, Queensland 4343, Australia
}

\begin{abstract}
Case study interviews were conducted with five tree farmers in Southern Leyte Province of Leyte Island in the Philippines. The case studies were designed to gain indepth insights into the problems and benefits of growing and managing trees from the perspective of the tree farmers. Interviews focussed on attitudes to regulations concerning the registration of tree plantings and transport of timber. Also discussed were the way in which tree farmers manage their trees, why they choose to manage a tree farm and their interactions with staff of the Philippine Department of Environment and Natural Resources. It was found that some tree farmers were motivated to plant trees after receiving free seedlings from the DENR and having positive interactions with DENR officers thereafter to help manage their farm and fulfil requirements of DENR policies. Tree farming was regarded as an effective way of improving living standards and welfare.
\end{abstract}

Keywords: in-depth interviewing, tree registration, free seedlings, harvest security, market information

\section{INTRODUCTION}

Currently on Leyte Island, the Philippines, reforestation and protection of natural forests is difficult, which in part can be attributed to the livelihoods of some people causing a damaging impact on the natural forests (Emtage 2004a). Additionally, the Philippines is one of the poorest countries in south-east Asia (Cramb 2000). People on Leyte Island tend to have their livelihoods focused around food security and cash income (Lasco and Pulhin 1999). This lack of opportunities and reliance on the land has resulted in damage to the natural resources of the Philippines. Devastation to the natural resources can be alleviated through rural development. Tree farming for smallholder farmers ${ }^{1}$ is perceived as being a viable land use for promoting rural development and improving the socio-economic situation of resource-poor people. However, the rate of tree planting by smallholders is low, for a variety of reasons, including lack of resources and concern over government regulations.

${ }^{1}$ Smallholder tree farmers can be defined as resource-constrained farmers (Mangaoang 2005 cited in Cedamon and Harrison 2005).

DOI: $10.32945 /$ atr2935.2007 
The Philippine Department of Environment and Natural Resources (DENR) has developed policies to encourage tree planting (Calub 2005). Tree farming in the Philippines has the potential to expand, due in part to encouragement from the DENR. A survey conducted by Emtage (2004b) found that about $60 \%$ of people surveyed in four rural communities on Leyte Island expressed an interest in commercial tree growing. However, only a small proportion of landholders undertake tree farming.

This paper reports findings of case studies about the way in which tree farmers in Maasin Community Environment and Natural Resource (CENR) district in Southern Leyte Province in the Philippines ${ }^{2}$ are managing their tree farms. This will provide input in reviews of policies and practices of DENR to encourage tree planting. The impact that DENR has on the way smallholders manage their tree farms, and the reason for their choice to grow trees, is discussed.

\section{RESEARCH METHOD}

In-depth interviewing ${ }^{3}$ was undertaken to gain insights into the management environment of individual tree farmers in Maasin CENRO area. A case study was conducted in which information was obtained from five tree farmers through personal interviews. This study site is shown in Figure 1. This area was chosen because it is a major tree farming area in comparison with other areas in Leyte.

Respondents were purposively selected ${ }^{4}$ based on criteria that would help to describe the management situation of a range of tree farmers in Maasin CENRO area. The selection criteria - reported in Table 1 - were developed through consultation with key stakeholders. These criteria are not mutually exclusive, that is, one respondent could meet a number of the criteria. Case study candidates were identified with assistance from the CENRO staff in Maasin ${ }^{5}$.

\footnotetext{
2 The structure of the Philippine Department of Environment and Natural Resources (DENR) involves a central office in Manila, regional or provincial offices, and Community Environment and Natural Resources Offices (CENROs) at a district level. Leyte Island, which consists of Leyte and Southern Leyte provinces, has five CENROs, one of which is in the Southern Leyte capital city of Maasin.

${ }^{3}$ In-depth interviewing does not necessarily use a preset list of questions to ask in turn. The purpose is to help the respondent feel they are able to speak openly about their thoughts and to gauge additional information not discernable through fixed questions.

${ }^{4}$ Purposive selection involves choosing respondents on the basis of the information already known about them.

${ }^{5}$ Initially, video-taping of interviews was planned, so that the case study 'stories' could be used in the IEC campaign of DENR, which is why willingness to be included in Video Compact Disk (VCD) extension materials was one of the criteria. Technical and cost difficulties lead to abandonment of this plan.
} 


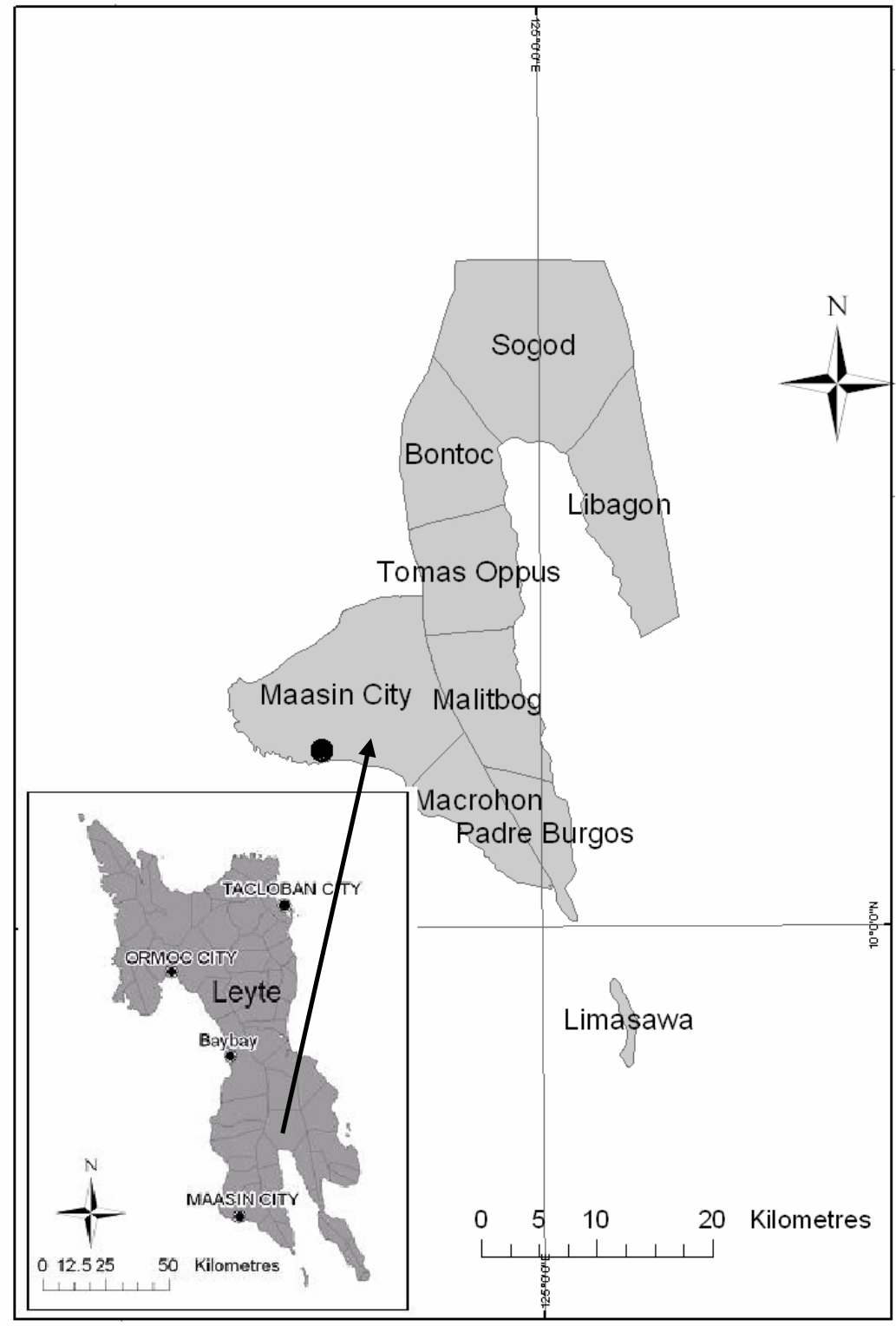

Figure 1. Community Environment and Natural Resources Offices areas of jurisdiction in the province of Southern Leyte

Source: Adapted from Farm and Resource Management Institute (2005). 
Table 1. Criterion used to select the five tree farmers for interview

\begin{tabular}{lc}
\hline Criterion & $\begin{array}{c}\text { Number of the five } \\
\text { respondents meeting } \\
\text { criterion }\end{array}$ \\
\hline $\begin{array}{l}\text { Willing to be included in Video Compact Disk (VCD) } \\
\text { extension materials }\end{array}$ & All \\
Tree farm located within Maasin CENRO jurisdictional area & All \\
From a low income bracket & At least 1 \\
Tree farm located on privately-owned land & All \\
Has an 'interesting' case to present & \\
Has registered their trees & All \\
Has not registered their trees & At least 1 \\
Has a plantation that is ready to harvest & At least 1 \\
Not interested in selling their timber & At least 1 \\
Have been provided with assistance from Maasin CENRO & At least 1 \\
\hline
\end{tabular}

Each respondent was interviewed on at least three separate occasions. Each meeting took about two hours. A set of guideline questions was used to help direct the flow of conversation. However, the interviews were informal and were conducted on the farmers' properties where inspections of the tree farms were made during the first visit. When appropriate, records of relevant permits and tree registration documents were copied by taking a photograph with a digital camera. Additionally, photographs were taken of the tree farm and respondent's family. Most importantly, trust between the respondent and researchers needed to be established in order gain greater insights into the social reality of the individual. The interviewers explained as clearly as possible to the respondent that their information would be for a good cause, that they would have the option to review and remove information recorded through follow-up visits, and that their names would be kept in confidence. Although it is not known to what degree each respondent trusted the interviewers, the respondents did state that they understood and supported the purpose of the interviews and hoped that some positive results would arise from the study. Subsequently, more in-depth information could be obtained on followup visits.

Recording of interviews was undertaken with an MP3 digital recorder ${ }^{7}$ in English and when necessary in Cebuano dialect. When interviews were conducted in Cebuano the responses were verbally translated immediately into English, so more questions could be asked in English. Information was transcribed from MP3 recordings shortly after each interview, and the typed transcripts were presented to respondents in order for the information to be verified. The information was then summarised into tables.

\footnotetext{
${ }^{6}$ With regard to criterion 7, what is viewed as 'interesting' represents a subjective view of what the researcher felt would provide an informative story to document major issues about tree registration.

${ }^{7}$ As noted by Knodel and Saengtienchai (1999), sound recording reduces the pressure on the interviewer to manually record all response information, helping them to concentrate on keeping a natural flow in conversation and to expand on the questions asked.
} 


\section{DESCRIPTION OF THE RESPONDENTS}

All the respondents had attended a high school (although not all had completed high school education) and all had children. They all had some knowledge of forestry policies through interaction with the CENRO. All had some friends working in Maasin CENRO, and only one did not receive free seedlings from the CENRO. Three of the respondents had an income of over PhP150,000 per year, one had an income of between PhP100,000 and PhP120,000 per year, and one earned less than PhP50,000 per year.

\section{MOTIVATIONS FOR TREE FARMING}

Table 2 reports the motivations respondents had for planting trees and the number of people who gave the same response. None of the respondents relied on tree farming as their sole source of income and most took the view that there is 'good money' in trees but it takes many years to derive the income. Only one of the respondents did not wish to derive any income from their trees and had planted for environmental reasons as well as to use timber for on-farm purposes. All respondents felt that tree farming was a worthwhile and financially viable venture. The respondent from the lower income bracket produced their own seedlings, with the seed collected from a tree growing near their home. In this case the CENRO had provided them with some training to understand how to grow and manage trees, as the respondent was involved in an integrated social forestry project of the DENR.

In all cases land was selected for planting which the owner knew would grow trees well, due to a recommendation by the DENR and observation that trees on neighbouring properties were growing well. Some of the respondents commented that nothing else would grow as well as trees because, in addition to a low rainfall, the land was too steep for growing crops. One respondent still had coconuts growing within their plantation, aiming to generate revenue in the short term and be less reliant on income from trees. Although there was just one respondent who specifically mentioned that aesthetic value was a main motivation for planting trees, all the other respondents appreciated the environment that the trees provided.

The four respondents who mentioned they planted the trees on behalf of their children did this for several reasons. One was that the children would receive the returns on the timber, and another was that the owners felt their children would enjoy the family commitment of growing and managing a tree farm. Also, these respondents felt that the family would benefit from using the timber themselves and would take pride in knowing they grew the timber themselves. 
Table 2. Respondents' motivation for planting trees

\begin{tabular}{lc}
\hline Motivation for planting trees & Number of responses \\
\hline Land is suitable for trees & 5 \\
For the children & 4 \\
Free seedlings were available from the CENRO & 4 \\
To derive income from the trees & 4 \\
To produce timber for own use & 4 \\
Wants an ongoing forestry business & 3 \\
Environmental protection & 2 \\
Aesthetic value & 1 \\
Land is not as suitable for coconuts & 1 \\
\hline
\end{tabular}

\section{SPECIES SELECTION AND TREE FARM MANAGEMENT}

The respondent who did not receive free seedlings from the CENRO had an area of 0.25 ha planted with trees. This respondent chose to plant gmelina (Gmelina arborea), bagalunga (Melia dubia) and mahogany (Swietenia macrophylla) because these seeds were available in the barangay. Species choice by the other respondents was greatly influenced by what species were available without charge from the CENRO. All of these four respondents had planted gmelina and three had planted mahogany. The respondents stated that species choice was based on resources (including free seedlings) available to them and recommendations by the CENRO. In these cases, there was evidence from others in the community who had planted the same species had derived positive results, which may also have influenced their species choice. The respondent who planted the trees mainly for aesthetic purposes chose to include native species, while all other respondents preferred to plant exotic species.

Management of the tree farms was greatly influenced by the advice given by the CENRO. The respondent who did not wish to derive income from the trees used brushing for weed control and applied organic fertiliser to the trees during establishment. This respondent planted the species available to them free from the CENRO, which included some nara (Pterocarpus indicus), an indigenous species which is the national tree of the Philippines. Table 3 reports the silviculture applied to the trees and why this was applied, as well as the advice provided by the CENRO.

Although thinning of trees was advised by the DENR, and all the respondents had trees old enough to be thinned, only one respondent had carried out thinning. Most had other crops including coconuts planted between the trees. One respondent commented that they would not plant any more coconuts, because these effected the growth of the gmelina trees, but they did not want to remove the coconuts already growing. The impression given to the interviewer was that respondents were not motivated to remove trees so as to reduce stand density before harvest age, although they

\footnotetext{
${ }^{8}$ In some cases the site capability - determined by the most limiting factor - was not favourable for other uses (i.e. crops) because of poor soil, steepness and in one case lack of water in the dry season.
} 
acknowledged this was probably a desirable practice. In addition, each respondent had sources of income other than managing trees and they all spent much of their spare time with their families. Although all respondents took pride in the fact they had established their own tree farm, they spent a relatively small proportion of their time managing their trees.

Table 3. Silviculture applied, reason for practice, and advice given by the CENRO

\begin{tabular}{|c|c|c|}
\hline Silviculture & Reason & $\begin{array}{l}\text { Whether advised by the } \\
\text { DENR }\end{array}$ \\
\hline $\begin{array}{l}\text { No thinning, but } \\
\text { would like to thin in } \\
\text { the future }\end{array}$ & $\begin{array}{l}\text { The bigger trees will get bigger } \\
\text { if the smaller trees are thinned }\end{array}$ & Yes \\
\hline Thinning & To improve tree growth & Yes \\
\hline Pruning & $\begin{array}{l}\text { To make the trees grow faster } \\
\text { and straighter }\end{array}$ & Yes \\
\hline Brushing & $\begin{array}{l}\text { Weed control, especially upon } \\
\text { establishment }\end{array}$ & Yes \\
\hline $\begin{array}{l}\text { Fertiliser upon } \\
\text { establishment }\end{array}$ & To increase the growth rate & $\begin{array}{l}\text { Yes, although one } \\
\text { respondent claimed that } \\
\text { little encouragement was } \\
\text { provided by the CENRO }\end{array}$ \\
\hline
\end{tabular}

The only respondent who did not hire labour for the management of the trees had an area of $0.25 \mathrm{ha}$. The other respondents, all of whom had a larger area, hired at least two labourers during establishment, which cost on average PhP120 per day. Two of the respondents felt that capital of about $\mathrm{PhP} 10,000$ was needed to establish and manage a tree farm of about 2 ha. The main silvicultural treatment applied to all tree farms was weed control through brushing - mostly during establishment - as advised by the CENRO. After establishment, the respondents did not put as much effort into looking after the trees. Furthermore, in all cases personal communication with the CENRO after the establishment occurred was minimal.

All the respondent's tree farms were situated on land which they felt was fertile, although in two of the sites the area was of relatively low soil fertility and lacked soil water in the dry season. This gave more motivation for tree planting considering the site was not as favourable for other crops. In one of the sites, the land was steep and the owners wanted trees to prevent erosion.

The method of choosing species and managing them was based on a combination of factors. Mainly, each respondent chose to follow the directions of the CENRO and prioritised their time devoted to tree farm management according to what other livelihood activities they undertook. In general, all respondents seemed relaxed about how they should best manage their trees and depended mostly on natural conditions to

\footnotetext{
${ }^{9}$ No respondent mentioned that pruning may improve the wood quality.
} 
bring about an acceptable growth rate. Although all respondents felt that sound management of trees was important, it was not a priority for their livelihoods.

\section{DENR POLICIES ASSOCIATED WITH TREE FARMING ON PRIVATE LAND}

All the respondents had some knowledge of DENR forestry policies, because all had some interaction with the CENRO in Maasin. However, there were some negative perceptions of tree registration policies in particular, as listed in Table 4. Although all respondents were encouraged by the CENRO to register their trees, one did not register. This respondent stated the view that someone who has planted trees themselves on their private land should not have to undertake tree registration. There were also positive perceptions of the policies, and three of the respondents felt that tree registration provided security to be able to prove ownership and harvest and sell their timber with the help of the DENR.

Table 4. Respondents' comments on DENR policies

Respondents' comments on policies

Laws are made for people and it should not be the other way around

Often dealings with the DENR are unfair for poor farmers

Tree registration gives harvest and transport security

Some policies are not fair

Tree registration and transport permits do not necessarily provide security for

harvest and transport without a problem

Tree registration is good because the trees are inventoried

Tree registration is easy and free

Even if tree registration costs money it is still a good policy

Tree registration should not be necessary

Table 4 shows that all respondents felt that tree registration and other policies were important for harvesting and transport because they help ensure that logging is legal, by proving ownership of the trees. Subsequently, all respondents felt that tree registration was a legal requirement. One respondent - who did not receive free seedlings from the CENRO - gained their knowledge about DENR policies from another tree farmer. Four of the five respondents - those who had registered their trees - felt that tree registration would provide security of ownership of the trees. The respondents who had applied for a transport permit did not have any difficulties securing this. However, one of the respondents that did not find it difficult to obtain a transport permit was agitated and discouraged because the Philippine National Police (PNP) apprehended their timber at a transport checkpoint. This respondent had provided all required documents and permits (including a tree registration certificate and transport permit) upon transporting the timber. At that point they cut down some of the seedlings on their property in frustration.

Table 5 reveals some variations and inconsistencies in the procedures and fees for meeting legal requirements. For example, some tree farmers had every tree 
inventoried as part of tree registration, whereas one had a random sample taken. Most of the respondents felt tree registration and other policies were warranted. However, one respondent felt that those who plant trees on their private land should not have to go through the inconvenience of meeting policy requirements, even if the process is free, because they did not wish to sell their timber, and planted mainly for aesthetic reasons ${ }^{10}$. However, the tree farmers who wished to harvest and sell timber felt that all the policies were an acceptable initiative of the DENR.

Table 5. Respondents' understanding of DENR policies and problems and perceived advantages of policies

\begin{tabular}{c|l|l|l|l}
\hline Respondent & $\begin{array}{l}\text { Knowledge of } \\
\text { policies }\end{array}$ & $\begin{array}{l}\text { Procedure taken } \\
\text { to meet legal } \\
\text { requirements }\end{array}$ & \multicolumn{1}{|c|}{$\begin{array}{c}\text { Problems with } \\
\text { policies }\end{array}$} & $\begin{array}{l}\text { Advantages of } \\
\text { policies }\end{array}$ \\
\hline 1 & $\begin{array}{l}\text { Has a general } \\
\text { understanding } \\
\text { of the policies } \\
\text { from the } \\
\text { CENRO }\end{array}$ & $\begin{array}{l}\text { Random } \\
\text { sampling } \\
\text { undertaken by } \\
\text { CENRO for tree } \\
\text { registration, and } \\
\text { transport permit } \\
\text { obtained }\end{array}$ & $\begin{array}{l}\text { None. Was happy to } \\
\text { pay P500 for a } \\
\text { cutting permit. But } \\
\text { felt it was incon- } \\
\text { venient to secure } \\
\text { certification of land } \\
\text { ownership from the } \\
\text { barangay captain }\end{array}$ & $\begin{array}{l}\text { Security. Felt } \\
\text { tree registration } \\
\text { is a legal } \\
\text { requirement and } \\
\text { is needed to sell } \\
\text { timber }\end{array}$ \\
\cline { 2 - 3 } 2 & $\begin{array}{l}\text { Trees measured } \\
\text { by CENRO for } \\
\text { tree registration, } \\
\text { also before } \\
\text { transport }\end{array}$ & $\begin{array}{l}\text { None. Tree } \\
\text { registration was free }\end{array}$ & \\
\hline 3 & $\begin{array}{l}\text { Has a general } \\
\text { understanding } \\
\text { of policies } \\
\text { through } \\
\text { communication } \\
\text { with a } \\
\text { neighbour }\end{array}$ & $\begin{array}{l}\text { Every tree was } \\
\text { measured for tree } \\
\text { registration }\end{array}$ & $\begin{array}{l}\text { Had timber } \\
\text { apprehended by the } \\
\text { PNP, even though } \\
\text { all permits were } \\
\text { applied for through } \\
\text { the CENRO. Led to } \\
\text { conflict between the } \\
\text { CENRO and PNP }\end{array}$ & \multicolumn{1}{|l}{} \\
\hline
\end{tabular}

\footnotetext{
${ }^{10}$ In this situation tree registration is not a legal requirement, but is still encouraged by the
} CENR in Maasin. 
Table 5. (Cont.) Respondents' understanding of DENR policies and problems and perceived advantages of policies

\begin{tabular}{c|l|l|l|l}
\hline Respondent & $\begin{array}{l}\text { Knowledge of } \\
\text { policies }\end{array}$ & $\begin{array}{l}\text { Procedure taken } \\
\text { to meet legal } \\
\text { requirements }\end{array}$ & $\begin{array}{c}\text { Problems with } \\
\text { policies }\end{array}$ & $\begin{array}{l}\text { Advantages of } \\
\text { policies }\end{array}$ \\
\hline 4 & $\begin{array}{l}\text { Has a general } \\
\text { understanding } \\
\text { of the policies } \\
\text { from the } \\
\text { CENRO }\end{array}$ & $\begin{array}{l}\text { Every tree was } \\
\text { measured and the } \\
\text { boundary } \\
\text { surveyed, as well } \\
\text { as photographs } \\
\text { taken for tree } \\
\text { registration }\end{array}$ & $\begin{array}{l}\text { Found it easy to } \\
\text { register trees, which } \\
\text { was free }\end{array}$ & \\
\hline 5 & $\begin{array}{l}\text { Limited } \\
\text { understanding } \\
\text { of tree } \\
\text { registration } \\
\text { processes }\end{array}$ & $\begin{array}{l}\text { Has not applied } \\
\text { for tree } \\
\text { registration or } \\
\text { other permits }\end{array}$ & $\begin{array}{l}\text { Believes that people } \\
\text { who pay tax should } \\
\text { have the right to use } \\
\text { trees on their land } \\
\text { without having to } \\
\text { register their trees }\end{array}$ & $\begin{array}{l}\text { Did not want to } \\
\text { harvest and felt } \\
\text { no need to } \\
\text { register trees, } \\
\text { but realises } \\
\text { would need to } \\
\text { register if } \\
\text { harvesting and } \\
\text { transporting }\end{array}$ \\
\hline
\end{tabular}

\section{INTERACTION WITH THE CENRO IN MAASIN}

Although all of the respondents had friends in the CENRO, one respondent still felt that the CENRO did not encourage them enough and did not provide enough advice on how to manage trees. Four of the five respondents, however, felt that they were given sound advice by the CENRO, including information on when to harvest, prune and thin, as well as policy information. One of the respondents was involved in an integrated social forestry project of the DENR and was able to learn - among other tree farm establishment and management practices - how to propagate seedlings. The specific advice provided by the CENR officers was considered an important factor in the establishment of the tree farms.

\section{KNOWLEDGE ABOUT MARKETING OF TIMBER}

Table 6 shows that nearly all the respondents gained information about how to market their timber due to advice from the CENRO, because buyers had also approached the CENRO. Obtaining the transport permit needed was also made easier after respondents had registered their trees. One of the respondents sought advice from a friend who had sought market information from the CENRO. One of the respondents who did not seek help from the CENRO to market their timber, did not wish to sell their timber, but said that if they chose to sell timber then the sale would be to a friend. 
As most respondent's avenue for gaining knowledge of markets was through the CENRO, their knowledge of average market prices offered for timber was limited. One respondent had compared prices between two buyers, while no other respondent had compared any prices. A couple of the respondents considered the money received from selling the timber as a bonus income and were not greatly concerned about finding the best offered price. The ones that sought advice from the CENRO trusted that these buyers would pay them close to what the timber was worth.

Table 6. Respondents' knowledge of markets for their timber

\begin{tabular}{lc}
\hline Knowledge of markets & $\begin{array}{c}\text { Number of } \\
\text { responses }\end{array}$ \\
\hline $\begin{array}{l}\text { The buyer only wanted to buy from the respondent if they had } \\
\text { registered their trees }\end{array}$ & 4 \\
The CENRO helped to market the timber & 3 \\
The buyer approached the CENRO for advice & 3 \\
The buyer was willing to pay for the transport permit & 1 \\
Accepted the market price as per advice from the contractors & 1 \\
Will sell to friends or a lumber dealer he already knows & 1 \\
Sought market advice from a friend & 1 \\
\hline
\end{tabular}

\section{CONCLUSION}

The information provided through case studies has helped to provide insights about the problems and benefits of growing trees, from the perspective of tree farmers. Many of the reasons for the adoption of tree farming and the way in which trees are managed have been influenced by the interactions of tree farmers with the CENRO in Maasin. In addition, tree farming has been used as an additional livelihood activity on top of other means of generating income. Due to factors including government policy, tree farm establishment and management, and marketing requirements, owning a tree farm requires significant mentoring for individual landholders to adopt as a viable livelihood activity. In all the cases investigated in this study, the respondents most probably would not have planted trees without CENRO input.

In summary, current circumstances show that tree farming is viable for people with other means of generating shorter-term income. Currently, tree farming requires substantial input from CENR officers in order for factors such as establishment, management, meeting policy requirements and marketing their timber to be met by individual landholders. More simplistic and consistent mechanisms for regulating DENR policies would assist CENR officers in helping people to fulfil legal requirements and encourage tree planting. Widespread tree planting might be achieved with more training and face-to-face advice provided to smallholders. 


\section{ACKNOWLEDGMENTS}

I would like to thank the Australian Centre for International Agricultural Research for providing funding support, and Eduardo Mangaoang, Rotacio Gravoso, Edwin Balbarino and Belita Vega for providing advice on the research method. Additionally, I would like to thank personnel of CENRO Maasin who provided information and guidance for the study. I thank Rosela B. Sabejon and Arniel Pogosa for helping to conduct fieldwork. I would like to thank Steve Harrison and Iean Russell for assistance in preparing this paper. Lastly, I would also like to thank the respondents of the study for patiently providing information about their tree farming.

\section{REFERENCES}

CALUB, F.S. 2005. DENR rules and regulations governing timber and timber products planted on private land. Annals of Tropical Research. 27(1): 91-96.

CEDAMON, E.D. and S.R. HARRISON. 2005. Fine-tuning the Leyte Tree Farm Research Project: Lessons from a planning workshop. In: ACIAR Smallholder Forestry Project - Improving Financial Returns to Smallholder Tree Farmers in the Philippines (J. Suh, S.R. Harrison, J.L. Herbohn, E.O. Mangaoang and J. Vanclay, eds). 15-17 Febuary 2005. Ormoc City, the Philippines. pp. 225-231.

CRAMB, R.A. 2000. Soil Conservation Strategies for Smallholder Farmers in the Philippine Uplands: a Socioeconomic Evaluation. Australian Centre for International Agricultural Research, Canberra.

EMTAGE, N.F. 2004a. Stakeholders' roles and responsibilities in the community-based forest management program of the Philippines. Small-scale Forest Economics, Management and Policy. 3(3): 319-336.

EMTAGE, N.F. 2004b. An Investigation of the Social and Economic Factors Affecting the Development of Small-scale Forestry in Leyte Province, the Philippines. PhD thesis submitted to the School of Natural and Rural Systems Management, The University of Queensland, Brisbane.

FARM AND RESOURCE MANAGEMENT INSTITUTE. 2005. Leyte State University, Visca, Baybay, Leyte.

KNODEL, J. and C. SAENGTIENCHAI. 1999. Studying living arrangements among the elderly: Lessons from a quasi-qualitative case study approach in Thailand. Journal of Cross-Cultural Gerontology. 14: 197-220.

LASCO, R.D. and F.B. PULHIN. (1999), Forestland Use Change in the Philippines and Climate Change Mitigation. College of Forestry and Natural Resources, University of the Philippines Los Baños. 